\title{
The Role of Purine Metabolites as DAMPs in Acute Graft-versus-Host Disease
}

\author{
Petya Apostolova and Robert Zeiser* \\ Department of Hematology, Oncology and Stem Cell Transplantation, University Medical Center, Albert Ludwig University of \\ Freiburg, Freiburg, Germany
}

Acute graft-versus-host disease (GvHD) causes high mortality in patients undergoing allogeneic hematopoietic cell transplantation. An early event in the classical pathogenesis of acute GvHD is tissue damage caused by the conditioning treatment or infection that consecutively leads to translocation of bacterial products [pathogen-associated molecular patterns (PAMPs)] into blood or lymphoid tissue, as well as danger-associated molecular patterns (DAMPs), mostly intracellular components that act as pro-inflammatory agents, once they are released into the extracellular space. A subtype of DAMPs is nucleotides, such as adenosine triphosphate released from dying cells that can activate the innate and adaptive immune system by binding to purinergic receptors. Binding to certain purinergic receptors leads to a pro-inflammatory microenvironment and promotes allogeneic T cell priming. After priming, T cells migrate to the acute GvHD target organs, mainly skin, liver, and the gastrointestinal tract and induce cell damage that further amplifies the release of intracellular components. This review summarizes the role of different purinergic receptors in particular P2X7 and P2Y2 as well as nucleotides in the pathogenesis of GvHD.

Keywords: graft-versus-host disease, P2X7, P2Y2, ATP, ectonucleotidase, inflammasome, uric acid, neutrophils

\section{INTRODUCTION}

Allogeneic hematopoietic cell transplantation (allo-HCT) is a potentially curative therapeutic option mainly for patients with acute leukemias or malignant lymphomas but also for selected non-malignant diseases. Initial transplantation attempts remained ineffective due to the lack of knowledge regarding human leukocyte antigen (HLA) compatibility between donor and recipient and the lack of adequate immunosuppressive drugs. Today, more than 60 years later, immunologic reactions between donor and host still remain one of the major causes of morbidity and mortality after allo-HCT. Here, we discuss the impact of purines as danger-associated molecular patterns (DAMPs) in the context of acute GvHD. We decided to focus on purines and their receptors in GvHD because other danger signals in the context of allo-HCT have been discussed in a previous review (1). Nucleosides and nucleotides bind to the P1 and P2 family of purinergic receptors. Whereas adenosine activates four receptors belonging to the P1 family, UDP (Uridine-5'-diphosphate), uridine-5' - triphosphate (UTP), adenosine diphosphate (ADP), and adenosine triphosphate (ATP) activate the large family of $\mathrm{P} 2$ receptors with a variable affinity. The $\mathrm{P} 2$ receptor family is divided into two subfamilies, the ligand-gated ion channels P2X receptors and the G-protein-coupled P2Y receptors. Purinergic signaling is regulated by the expression of cell surface enzymes known as ectonucleotidases, most 
prominently CD39 and CD73 that convert ATP/UTP to ADP/ UDP and ultimately to the respective nucleosides adenosine and uridine. Purinergic signaling modulates inflammation on multiple levels and contributes to the pathogenesis of a broad variety of diseases besides GvHD. P1 and P2 receptors show a variable distribution among different tissues that ensures a broad spectrum of effects. For instance, the P2Y2 receptor is expressed on immune cells but also on epithelial and endothelial cells and osteoblasts. Expression of the P2X7 receptor is predominant on immune cells, such as antigen-presenting cells, but is also found in the skin and pancreas (2). Expression of the P2Y12 receptor on platelets is a key feature for the use of P2Y12 receptor antagonists in the clinic.

\section{PURINERGIC SIGNALING IN CARDIOVASCULAR DISEASE}

Purinergic signaling has a well-established role in cardiovascular disease on multiple levels. For instance, nucleotides play a role in the formation of atherosclerotic plaques as a result of lipid metabolism dysregulation. In a murine model of atherosclerosis with apolipoprotein E-deficient mice, lack of the P2Y12 receptor was linked to a reduced plaque lesion area, decreased monocyte infiltration, and enhanced fibrous content of the plaque (3). In this same model, deficiency of the P2Y1 receptor significantly decreased the expression of vascular adhesion molecules P-selectin, VCAM-1, and ICAM-1 leading to diminished recruitment of leukocytes to lesion sites (4). Furthermore, endothelial cell cytoskeleton, motility, and adhesion are regulated via activation of the P2Y2 receptor following ATP or UTP binding (5). This is of particular importance due to the fact that the P2Y2 receptor is upregulated in the neointima of injured arteries in rats (6). Nucleotide binding to the P2Y2 receptor results in co-localization of the P2Y2 and VEGFR2 with subsequent upregulation of VCAM-1 that facilitates leukocyte adhesion (7). Endothelial cell migration is enhanced upon binding of $\mathrm{ADP}$ to the $\mathrm{P} 2 \mathrm{Y} 1$ receptor via activation of the mitogen-activated protein kinase pathways (8). Last but not least, purinergic signaling has long been known to modulate platelet aggregation (9), mostly by ADP binding to the P2Y12 receptor (10). This fact led to the utilization of P2Y12 receptor antagonists, such as clopidogrel for inhibition of platelet aggregation for multiple cardiovascular diseases in patients (Table 1). Taken together, these data indicate that release of nucleotides with subsequent activation of purinergic receptor is a pro-inflammatory stimulus that enhanced leukocyte binding to the endothelium, platelet aggregation, and subsequent atherosclerotic plaque formation. Given the fact that multiple receptors have been implied to play a role, a more general purinergic receptor blockade might be required in order to achieve optimal protection.

\section{PURINERGIC SIGNALLING IN AIRWAY INFLAMMATION}

In the context of airway inflammation, purinergic signaling also plays a significant role in the activation of immune cells (Table 1). For instance, increased ATP levels following allergen challenge recruit airway-specific myeloid cells and induce Th2 cell polarization and eosinophilic airway inflammation, which are major features of allergic asthma in humans. Neutralization of ATP signaling abrogated airway inflammation in response to allergens (11). Further studies emphasized the role of P2X7 receptor expression on dendritic cells (DCs) in this context (12). However, purinergic receptor expression is not limited only to the immune cell compartment. The P2Y6 receptor was found on airway epithelial cells with abundant expression upon allergen challenge and its inhibition by synthetic antagonists or the genetic deletion reduced IL- 6 and IL- 8 secretion by epithelial cells and improved disease outcome in a murine model (13). More recent studies suggest that purinergic signaling

TABLE 1 | Purinergic signaling and ectonucleotidases in inflammatory diseases.

\begin{tabular}{|c|c|c|}
\hline Disease context & Mechanism & Reference \\
\hline Airway inflammation & ATP triggers airway inflammation via P2X7 expression on dendritic cells & $(11,12)$ \\
\hline Airway inflammation & P2Y6 receptor expressed on lung epithelial cells mediates IL-6 and IL-8 secretion upon allergen challenge & (13) \\
\hline Airway inflammation & ATP activation of the P2Y2 receptor contributes to eosinophilic lung inflammation & $(44,45)$ \\
\hline Cardiovascular disease & P2Y12 receptor deficiency reduces monocyte infiltration and plaque lesion area & (3) \\
\hline Cardiovascular disease & Lack of the P2Y1 receptor decreases leukocyte infiltration into atherosclerotic plaques & (4) \\
\hline Cardiovascular disease & Neointima injury results in upregulation of the P2Y2 receptor in rats, which in turn promotes leukocyte adhesion & $(6,7)$ \\
\hline GvHD & ATP released from damaged cells aggravates GvHD by activation of antigen-presenting cells & $(23,73)$ \\
\hline GvHD & P2Y2 deficiency in monocytes reduces GvHD severity by abrogating ERK activation and ROS production & $(50)$ \\
\hline GvHD & CD73 deficiency increases T cell allo-reactivity and aggravates murine GvHD & $(65,66)$ \\
\hline \multirow[t]{2}{*}{ Inflammatory bowel disease } & CD39 deletion aggravates chemically induced colitis in mice & $(57,60)$ \\
\hline & CD39 expression on Tregs is associated with better therapy response in inflammatory bowel disease patients & \\
\hline Inflammatory bowel disease & Lack of CD73 aggravates experimental inflammatory bowel disease in mice & (64) \\
\hline Ischemia-reperfusion injury & CD39 plays a protective role by reducing vascular leakage & (56) \\
\hline Lupus-associated nephritis & Inhibition of the P2X7 receptor reduces nephritis severity & $(17)$ \\
\hline \multirow[t]{2}{*}{ Multiple sclerosis } & ATP increases oligodendrocyte excitotoxicity and plaque formation via binding the P2X7 receptor & $(15,16)$ \\
\hline & Gain of function polymorphisms of the P2X7 receptor are associated with increased MS risk & \\
\hline Platelet aggregation & Inhibition of P2Y12 signaling blocks platelet aggregation & $(10)$ \\
\hline
\end{tabular}


might be regulated by microRNAs. There is evidence that the immunomodulatory miR-155 is necessary for intact purinergic signaling. Lack of miR-155 resulted in impaired DC chemotaxis toward pro-inflammatory stimuli with subsequently reduced airway inflammation in mice (14).

\section{PURINERGIC SIGNALING IN AUTOIMMUNITY}

Purine nucleotide-mediated signaling has been implied in autoimmune diseases, including multiple sclerosis (MS), psoriasis, and nephritis among others (Table 1).

$\mathrm{P} 2 \mathrm{X} 7$ receptor activation by ATP binding triggers oligodendrocyte excitotoxicity and increases MS plaque formation in an experimental autoimmune encephalomyelitis model. More importantly, P2X7 receptor upregulation is observed in healthy tissue of MS patients, suggesting that inhibition of purinergic signaling might be a novel therapeutic target (15). In line with these data, a signal nucleotide polymorphism in the human $p 2 x 7 r$ gene that leads to a gain of function amino acid exchange, occurs more frequently in MS patients than in healthy controls (16). P2X7 receptor upregulation was also observed in lesional and non-lesional skin of psoriasis patients. In lupus-associated nephritis, P2X7 receptor antagonists reduced nephritis severity, pro-inflammatory serum cytokines, and NLRP3 inflammasome activation underlying once more the broad therapeutic potential of these pathways (17).

\section{THE ROLE OF P2X7 IN GvHD}

ATP is a molecule with a high intracellular concentration that is released upon cell stress. In the absence of tissue damage, the intracellular ATP concentration ranges from 3 to $10 \mathrm{mM}$, while extracellular ATP levels are as low as $10 \mathrm{nM}$. This balance is regulated by ectonucleotidases, such as CD39 and CD73, which dephosphorylate ATP to ADP, AMP, and ultimately generate adenosine $(2,18,19)$. The $\mathrm{P} 2 \mathrm{X} 7$ receptor is a cation channel activated by high concentrations of ATP (20). P2X7 plays a central role for IL- $1 \beta$ secretion via activation of the NACHT, LRR, and PYD domains-containing protein 3 (Nlrp3) inflammasome $(21,22)$. We observed that release of ATP from damaged cells after allo-HCT amplified acute GvHD (23) via enhanced maturation of APCs and reduced Treg numbers. Besides activation via P2X7, the Nlrp3 inflammasome can be activated by uric acid (24) and Syk signaling (25). We found that uric acid enhanced GvHD in the early phase after allo-HCT (26). Inhibition of Syk reduced GvHD-related mortality in the mouse model without impairing anti-MCV or anti-leukemia responses (27). After tissue damage due to chemotherapy of irradiation, neutrophil granulocytes (neutrophils) and inflammatory monocytes reach a site of inflammation particularly early and participate in the first line of defense. Different studies have shown the chemotactic role of ATP for neutrophil chemotactic recruitment $(28,29)$. It was shown that purinergic signaling causes strong activation of human neutrophils (30) and activated neutrophils can release ATP through pannexin-1 hemichannels by an active process, which means that the process consumes energy (30). Neutrophils release reactive oxygen species (ROS) upon activation with bactericidal activity and the potential to cause local tissue damage $(31,32)$ that was shown to enhance GvHD (33) (Table 1). The mechanism as to how DAMPs, PAMPs, and neutrophils may contribute to GvHD is depicted in Figure 1. Besides neutrophils (33-35), other myeloid cell populations in particular DCs (36), macrophages $(37)$, and certain monocyte subsets $(38,39)$ were found to enhance or reduce GvHD. Different purinergic receptors were found to be expressed by these myeloid cells (2) and their activation modifies the immune response elicited by the respective myeloid cell type. Myeloid-derived suppressor cells (MDSC) that lack a function Nlrp3 inflammasome are more protective against GvHD compared to WT MDSC (40), indicating that a functional Nlrp3 inflammasome modifies the inflammatory phenotype of this myeloid cell type. Besides MDSCs, DCs were shown to be influenced by different signals from purinergic receptors. To present the antigen that was taken up at the site of inflammation by a DC, costimulation is required. ATP is involved in this process as it enhances the maturation of human monocytederived DCs with increased levels of costimulatory molecules (41, 42). Recently, the central role of donor-derived colonic CD103+ DCs in Ag presentation to donor T cells that then induce GvHD was reported (43). These reports from different groups support the concept that P2X7 activation in myeloid cells enhances their inflammatory phenotype that then promotes $\mathrm{T}$ cell priming and inflammation that ultimately lead to GvHD.

\section{THE ROLE OF P2Y2 IN GvHD AND INFLAMMATION}

The activation of $\mathrm{P} 2 \mathrm{Y} 2$ was shown to promote tissue damage in airway inflammation $(44,45)$ and acute liver injury (46). However, P2Y2 was also shown to have protective effects in a model of lung infection induced by pneumonia virus of mice (47). P2Y2 can be activated by different nucleotides, the P2Y2 ligand ATP was found in different inflammatory diseases, including inflammatory bowel disease (48), glomerulonephritis (49), asthma (11), and diabetes (48). We recently reported that P2y2 deficiency of the recipient caused lower levels of myeloperoxidase in the intestinal tract of mice developing GvHD (50). Selective deficiency of P2Y2 in inflammatory monocytes lead to reduced GvHD severity (50) and $P 2 y 2^{-1-}$ inflammatory monocytes had defective ERK activation and ROS production. Besides these results in the mouse model, histochemical analysis of patient samples revealed that the frequency of $\mathrm{P} 2 \mathrm{Y} 2^{+}$cells in inflamed GvHD lesions correlated with histopathological GvHD severity.

\section{PURINERGIC SIGNALING AND THE GRAFT-VERSUS-TUMOR EFFECT}

Transplanation of the donor immune system into the allo-HCT recipient provides the graft-versus-tumor (GvT) effect that ensures long-term control of the underlying malignancy. Due to the fact that most treatments reduce the activation of the immune 


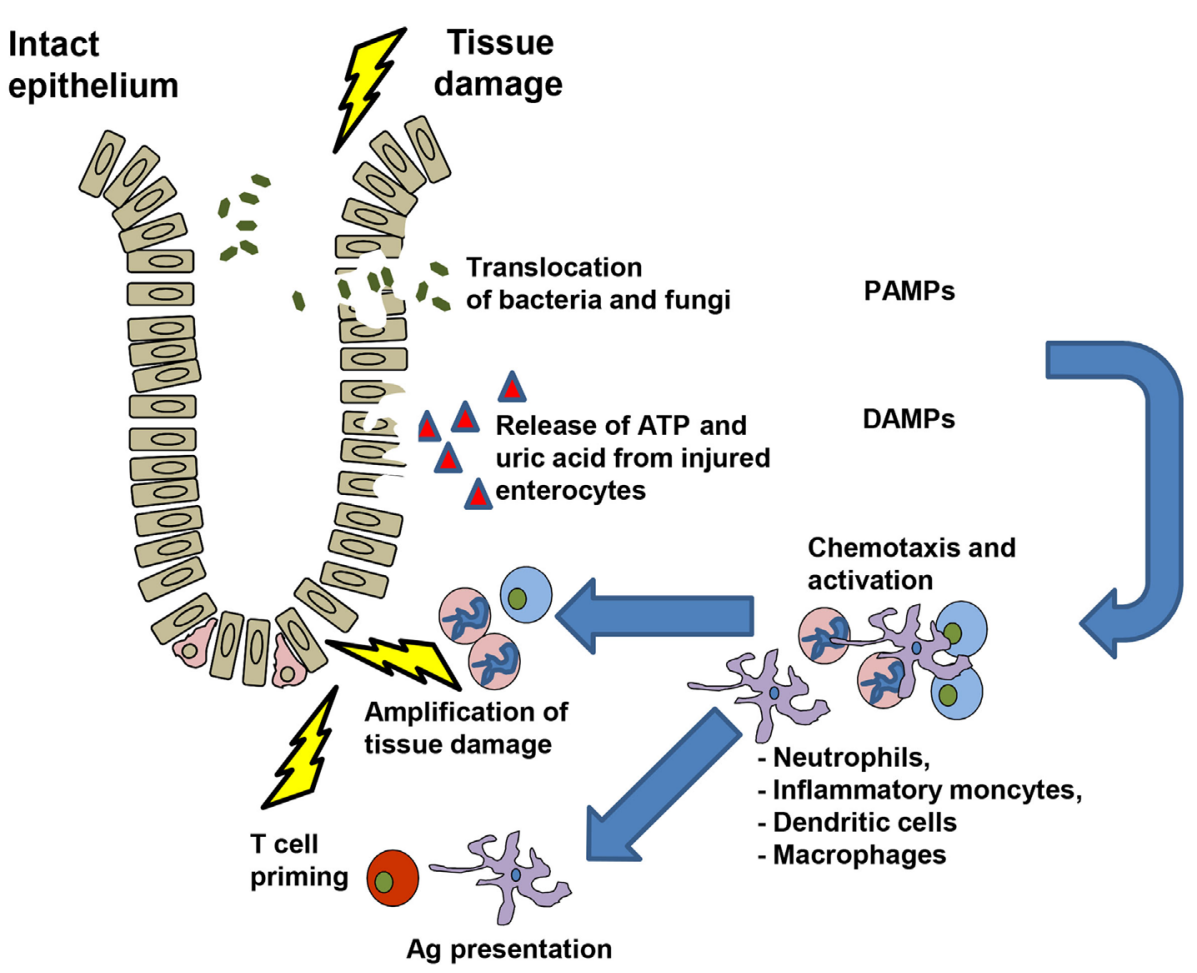

FIGURE 1 | DAMPs, PAMPs and immune cell interactions during GvHD development.

system, preserving the GvT effect is a major issue in posttransplant care. Interestingly, reduction of GvHD by application of the broad-spectrum P2R inhibitor PPADS did not interfere with the GvT effect, likely due to the fact that $\mathrm{CD}^{+} \mathrm{T}$ cell function is independent of purinergic signaling (23). On the other hand, A2A-AR expression on T cells allows adenosine to reduce allo-reactivity in a murine allo-HCT model, so that blockade of adenosine production allows for a more potent GvT effect at the cost of aggravated GvHD (51). These data suggest that purinergic receptor expression on $\mathrm{T}$ cells is crucial for the modulation of the GvT effect and offers a few therapeutic perspectives. On the one hand, in cases where a functional GvT effect is required, such as high-risk malignancies, a P2R inhibition might be a successful approach that reduces GvHD but leaves the GvT effect untouched. On the contrary, when performing allo-HCT in a patient with a benign hematopoietic disease without a necessity for a GvT activity, adenosine signaling might be enhanced as a therapy strategy for GvHD.

\section{MECHANISMS TO COUNTERBALANCE THE EFFECTS OF NUCLEOTIDES}

\section{Impact of the Ectonucleotidases CD39 and CD73 on Purinergic Signaling}

Purine nucleotides are naturally metabolized by ectonucleotidases - cell surface enzymes with catabolic activity in the extracellular space. Two ectonucleotidases have been mainly proposed in the context of inflammation and GvHD so far - CD39 and CD73 (ecto-5' -nucleotidase). While CD39 catabolizes the first two steps in purine metabolization, mainly the dephosphorylation of ATP to ADP and AMP, CD73 is involved in the last step, namely the generation of adenosine from AMP. Adenosine itself is a potent anti-inflammatory mediator that binds to the four receptors belonging to the $\mathrm{P} 1$ receptor family and counteracts the effects of the pro-inflammatory ATP (51). Ectonucleotidase activity counterbalances the effects of nucleotides by regulating their concentration in the extracellular space. Concomitant expression of CD39 and CD73 is observed, for example, on regulatory T cells (52) and multipotent mesenchymal stromal cells (53). Activity of soluble recombinant CD39 removes ATP and ADP from the extracellular space and inhibits platelet aggregation in vitro (54). However, CD39 seems to play a dual role in hemostasis, as CD39deficient mice exhibited prolonged bleeding times resulting from P2Y1 receptor desensitization (55). CD39 activity protects in the context of ischemia-reperfusion injury by modulation of vascular leakage (56). Furthermore, CD39 deletion rendered mice more susceptible to chemically induced murine colitis (57).

With regard to GvHD, recent studies demonstrate that CD39 activity on regulatory $\mathrm{T}$ cells induces the expression of the A2A-adenosine receptor on conventional $\mathrm{T}$ cells (58). Moreover, CD39-mediated adenosine signaling is important for the regulatory $\mathrm{T}$ cell-mediated inhibition of NOTCH1 signaling in conventional T cells (58), which is a known protective mechanism in the context of acute GvHD (59). Additionally, higher CD39 levels were found on regulatory $\mathrm{T}$ cells of inflammatory 
bowel disease patients in clinical remission when compared to non-responders (60).

Generation of adenosine from AMP via CD73 is mostly known as an anti-inflammatory reaction that dampens the pro-inflammatory cascades following ATP accumulation. In rheumatoid arthritis, lack of CD73 enhanced disease development, including Th1 cell differentiation, cytokine production, and joint destruction, and this was reversed by administration of a selective A2A-adenosine receptor agonist (61). In addition, decreased levels of CD73 were found on the surface of synovial fluid mononuclear cells in children with juvenile idiopathic arthritis (62). The immunosuppressive role of CD73 is also shown by the fact that mice lacking this molecule are more prone to autoimmune glomerulonephritis (63) and inflammatory bowel disease (64).

In the context of allo-HCT, we and others have previously shown that CD73 and adenosine modulate the severity of GvHD but might also represent a target for the enhancement of the graftversus-leukemia $(\mathrm{GvL})$ effect $(65,66)$. In absence of CD73 and adenosine, alloreactive $\mathrm{T}$ cells show a stronger proliferation with increased secretion of pro-inflammatory cytokines and improved migration capacity. This more aggressive $T$ cell phenotype translates into more pronounced GvHD severity, but also offers a target for enhancing the GvL effect in the context of allo-HCT (67).

CD73 and adenosine seem to play a differential role in inflammation, depending on the disease model, since recent studies suggest that CD73 might potentiate inflammation in the context of atherosclerotic plaque formation (68) and radiation-induced lung fibrosis (69).

\section{P1 and P2 Receptor Modulation}

The broad role of purinergic signaling in inflammation suggests a great therapeutic potential for compounds which modulate purinergic receptor signaling. P2Y12 receptor blockers, such as clopidogrel have now long been employed for inhibition of platelet aggregation.

Another receptor with a promising role in immune responses is the $\mathrm{P} 2 \mathrm{X} 7$ receptor. Preclinical studies have suggested a beneficial role for P2X7 blockade in allograft vasculopathy (70) ischemia-reperfusion injury (71), acute lung injury (72), and $\operatorname{GvHD}(23,73)$ among others. Also blocking downstream effects of P2X7, namely Nlrp3 inflammasome activation reduced GvHD in different models $(26,74,75)$. However, first clinical trials with $\mathrm{P} 2 \mathrm{X} 7$ receptor antagonists proved to be disillusioning. Phase II clinical trials with the compound AZD9056 could not show a reliable benefit in the treatment of patients with rheumatoid arthritis $(76,77)$ or Crohn's disease $(78)$. These data indicate that inhibition of $\mathrm{P} 2 \mathrm{X} 7$ receptor signaling might be a powerful target to modulate inflammation but there is still need for development of active compounds for the clinical setting.

Adenosine is the counterpart of the pro-inflammatory nucleotides ATP, ADP, UTP, and UDP. Adenosine is mostly generated among others by regulatory $\mathrm{T}$ cells and binds to the four receptors belonging to the $\mathrm{P} 1$ receptor family, $\mathrm{A} 1, \mathrm{~A} 2 \mathrm{~A}, \mathrm{~A} 2 \mathrm{~B}$, and $\mathrm{A} 3$ adenosine receptor. In the context of inflammation, the A2A receptor has been implied as anti-inflammatory in a wide spectrum of preclinical disease models.

A2A receptor agonists showed beneficial effects also in preclinical models of rheumatoid arthritis (79), encephalomyelitis (80), and allergic asthma (81). A2A receptor involvement in GvHD has also been shown by our group and others. A2A receptor expression on alloreactive $\mathrm{T}$ cells is critical for the integration of the protective CD73-mediated adenosine signaling (65). Treatment with a selective A2A receptor agonist, ATL146e inhibited T cell activation and reduced GvHD severity (82). These data were confirmed using other A2A receptor agonists with increased frequency of regulatory $\mathrm{T}$ cells in the GvHD target tissues (83). Numerous early clinical trials with adenosine receptor agonists are ongoing or have been completed recently, including indications such as psoriasis, rheumatoid arthritis, sickle cell anemia, myocardial reperfusion, and nerve injury (84) and hold promise to become part of the therapeutic arsenal against inflammatory diseases. To interfere with a broad activation signal as it is exerted by nucleotides the inhibition of the central signal is most promising and modification of TCR signaling can lead to Treg development (85). Besides purinergic receptor inhibition promising targets are the $\gamma_{c}$ receptor $(86)$ or Janus kinases $(87,88)$.

\section{SUMMARY}

Purinergic signaling belongs as a DAMP to the intrinsic mechanisms for inflammation regulation without pathogen exposure. Differential receptor expression is observed on various cell and tissue types, indicating distinct roles of purines depending on the particular disease context. In general, nucleotides as ADP, ATP, UDP, and UTP serve as "alarmins" and activate neutrophil granulocytes, macrophages, DCs, and platelets. On the other hand, adenosine produced by regulatory $\mathrm{T}$ cells or mesenchymal stem cells counteracts the effects of the nucleotides by binding to $\mathrm{P} 1$ receptors. The findings from multiple groups in different models of pathogenic inflammation indicate a central function of different purinergic receptors, such as P2X7 and P2Y2, in ATP-activated recipient myeloid cells during GvHD, which could be exploited when targeting danger signals to prevent GvHD. Current efforts are concentrating on the development of bioavailable and efficient compounds for the conduct of clinical trials.

\section{AUTHOR CONTRIBUTIONS}

The review article was designed and written by RZ together with the first author PA. Both performed literature review and critical discussion of the published literature.

\section{FUNDING}

RZ is funded by the DFG (Heisenberg Professorship). 


\section{REFERENCES}

1. Ramadan A, Paczesny S. Various forms of tissue damage and danger signals following hematopoietic stem-cell transplantation. Front Immunol (2015) 6:14. doi:10.3389/fimmu.2015.00014

2. Zeiser R, Robson SC, Vaikunthanathan T, Dworak M, Burnstock G. Unlocking the potential of purinergic signaling in transplantation. Am J Transplant (2016). doi:10.1111/ajt.13801

3. Li D, Wang Y, Zhang L, Luo X, Li J, Chen X, et al. Roles of purinergic receptor P2Y, G protein-coupled 12 in the development of atherosclerosis in apolipoprotein E-deficient mice. Arterioscler Thromb Vasc Biol (2012) 32(8):e81-9. doi:10.1161/ATVBAHA.111.239095

4. Zerr M, Hechler B, Freund M, Magnenat S, Lanois I, Cazenave JP, et al. Major contribution of the $\mathrm{P} 2 \mathrm{Y}(1)$ receptor in purinergic regulation of TNFalphainduced vascular inflammation. Circulation (2011) 123(21):2404-13. doi:10.1161/CIRCULATIONAHA.110.002139

5. Kaczmarek E, Erb L, Koziak K, Jarzyna R, Wink MR, Guckelberger O, et al. Modulation of endothelial cell migration by extracellular nucleotides: involvement of focal adhesion kinase and phosphatidylinositol 3-kinase-mediated pathways. Thromb Haemost (2005) 93(4):735-42. doi:10.1160/TH0409-0576

6. Seye CI, Gadeau AP, DaretD, Dupuch F, Alzieu P, Capron L, etal. Overexpression of P2Y2 purinoceptor in intimal lesions of the rat aorta. Arterioscler Thromb Vasc Biol (1997) 17(12):3602-10. doi:10.1161/01.ATV.17.12.3602

7. Seye CI, Yu N, Jain R, Kong Q, Minor T, Newton J, et al. The P2Y2 nucleotide receptor mediates UTP-induced vascular cell adhesion molecule-1 expression in coronary artery endothelial cells. J Biol Chem (2003) 278:24960-5. doi:10.1074/jbc.M301439200

8. Shen J, DiCorleto PE. ADP stimulates human endothelial cell migration via P2Y1 nucleotide receptor-mediated mitogen-activated protein kinase pathways. Circ Res (2008) 102(4):448-56. doi:10.1161/CIRCRESAHA. 107.165795

9. Jin J, Kunapuli SP. Coactivation of two different G protein-coupled receptors is essential for ADP-induced platelet aggregation. Proc Natl Acad Sci U S A (1998) 95(14):8070-4. doi:10.1073/pnas.95.14.8070

10. Foster CJ, Prosser DM, Agans JM, Zhai Y, Smith MD, Lachowicz JE, et al. Molecular identification and characterization of the platelet ADP receptor targeted by thienopyridine antithrombotic drugs. JClin Invest (2001) 107(12):1591-8. doi:10.1172/JCI12242

11. Idzko M, Hammad H, van Nimwegen M, Kool M, Willart MA, Muskens F, et al. Extracellular ATP triggers and maintains asthmatic airway inflammation by activating dendritic cells. Nat Med (2007) 13:913-9. doi:10.1038/ $\mathrm{nm} 1617$

12. Muller T, Vieira RP, Grimm M, Durk T, Cicko S, Zeiser R, et al. A potential role for P2X7R in allergic airway inflammation in mice and humans. Am J Respir Cell Mol Biol (2011) 44(4):456-64. doi:10.1165/rcmb.2010-0129OC

13. Vieira RP, Muller T, Grimm M, von Gernler V, Vetter B, Durk T, et al. Purinergic receptor type 6 contributes to airway inflammation and remodeling in experimental allergic airway inflammation. Am J Respir Crit Care Med (2011) 184(2):215-23. doi:10.1164/rccm.201011-1762OC

14. Chen S, Smith BA, Iype J, Prestipino A, Pfeifer D, Grundmann S, et al. MicroRNA-155-deficient dendritic cells cause less severe GvHD through reduced migration and defective inflammasome activation. Blood (2015) 126:103-12. doi:10.1182/blood-2014-12-617258

15. Matute C, Torre I, Perez-Cerda F, Perez-Samartin A, Alberdi E, Etxebarria E, et al. P2X(7) receptor blockade prevents ATP excitotoxicity in oligodendrocytes and ameliorates experimental autoimmune encephalomyelitis. J Neurosci (2007) 27(35):9525-33. doi:10.1523/JNEUROSCI.0579-07.2007

16. Oyanguren-Desez O, Rodriguez-Antiguedad A, Villoslada P, Domercq M, Alberdi E, Matute C. Gain-of-function of P2X7 receptor gene variants in multiple sclerosis. Cell Calcium (2011) 50(5):468-72. doi:10.1016/ j.ceca.2011.08.002

17. Zhao J, Wang H, Dai C, Wang H, Zhang H, Huang Y, et al. P2X7 blockade attenuates murine lupus nephritis by inhibiting activation of the NLRP3/ ASC/caspase 1 pathway. Arthritis Rheum (2013) 65(12):3176-85. doi:10.1002/ art.38174

18. Robson SC, Sevigny J, Zimmermann H. The E-NTPDase family of ectonucleotidases: structure function relationships and pathophysiological significance. Purinergic Signal (2006) 2(2):409-30. doi:10.1007/s11302-006-9003-5
19. Zimmermann H. Extracellular metabolism of ATP and other nucleotides. Naunyn Schmiedebergs Arch Pharmacol (2000) 362(4-5):299-309. doi:10.1007/s002100000309

20. North RA. Molecular physiology of P2X receptors. Physiol Rev (2002) 82(4):1013-67. doi:10.1152/physrev.00015.2002

21. Mariathasan S, Weiss DS, Newton K, McBride J, O’Rourke K, Roose-Girma $\mathrm{M}$, et al. Cryopyrin activates the inflammasome in response to toxins and ATP. Nature (2006) 440:228-32. doi:10.1038/nature04515

22. Ferrari D, Pizzirani C, Adinolfi E, Lemoli RM, Curti A, Idzko M, et al. The P2X7 receptor: a key player in IL-1 processing and release. J Immunol (2006) 176:3877-83. doi:10.4049/jimmunol.176.7.3877

23. Wilhelm K, Ganesan J, Müller T, Dürr C, Grimm M, Beilhack A, et al. Graft-versus-host disease enhanced by extracellular adenosine triphosphate activating P2X7R. Nat Med (2010) 12:1434-8. doi:10.1038/nm.2242

24. Martinon F, Petrilli V, Mayor A, Tardivel A, Tschopp J. Gout-associated uric acid crystals activate the NALP3 inflammasome. Nature (2006) 440:237-41. doi:10.1038/nature04516

25. Gross O, Poeck H, Bscheider M, Dostert C, Hannesschläger N, Endres S, et al. Syk kinase signalling couples to the Nlrp3 inflammasome for anti-fungal host defence. Nature (2009) 459:433-6. doi:10.1038/nature07965

26. Jankovic D, Ganesan J, Bscheider M, Stickel N, Weber F, Guarda G, et al. The Nlrp3-inflammasome regulates acute graft-versus-host disease. J Exp Med (2013) 210:1899-910. doi:10.1084/jem.20130084

27. Leonhardt F, Zirlik K, Buchner M, Prinz G, Hechinger AK, Gerlach UV, et al. Spleen tyrosine kinase (Syk) is a potent target for GvHD prevention at different cellular levels. Leukemia (2012) 26:1617-29. doi:10.1038/leu.2012.10

28. McDonald B, Pittman K, Menezes GB, Hirota SA, Slaba I, Waterhouse CC, et al. Intravascular danger signals guide neutrophils to sites of sterile inflammation. Science (2010) 330:362-6. doi:10.1126/science.1195491

29. Chen Y, Corriden R, Inoue Y, Yip L, Hashiguchi N, Zinkernagel A, et al. ATP release guides neutrophil chemotaxis via P2Y2 and A3 receptors. Science (2006) 314(5806):1792-5. doi:10.1126/science.1132559

30. Chen Y, Yao Y, Sumi Y, Li A, To UK, Elkhal A, et al. Purinergic signaling: a fundamental mechanism in neutrophil activation. Sci Signal (2010) 3(125):ra45. doi:10.1126/scisignal.2000549

31. Lucattelli M, Cicko S, Muller T, Lommatzsch M, de Cunto G, Cardini S, et al. P2X7 receptor signalling in the pathogenesis of smoke-induced lung inflammation and emphysema. Am J Respir Cell Mol Biol (2010) 44(3):423-9. doi:10.1165/rcmb.2010-0038OC

32. Lommatzsch M, Cicko S, Muller T, Lucattelli M, Bratke K, Stoll P, et al. Extracellular adenosine triphosphate and chronic obstructive pulmonary disease. Am J Respir Crit Care Med (2010) 181(9):928-34. doi:10.1164/ rccm.200910-1506OC

33. Schwab L, Goroncy L, Palaniyandi S, Gautam S, Triantafyllopoulou A, Mocsai A. Neutrophil granulocytes recruited upon translocation of intestinal bacteria enhance GvHD via tissue damage. Nat Med (2014) 20:648-54. doi:10.1038/nm.3517

34. Giroux M, Delisle JS, Gauthier SD, Heinonen KM, Hinsinger J, Houde B, et al. SMAD3 prevents graft-versus-host disease by restraining Th1 differentiation and granulocyte-mediated tissue damage. Blood (2011) 117:1734-44. doi:10.1182/blood-2010-05-287649

35. Socié G, Mary JY, Lemann M, Daneshpouy M, Guardiola P, Meignin V, et al. Prognostic value of apoptotic cells and infiltrating neutrophils in graft-versus-host disease of the gastrointestinal tract in humans: TNF and Fas expression. Blood (2004) 103:50-7. doi:10.1182/blood-2003-03-0909

36. ShlomchikW, Couzens MS, TangCB, McNiffJ, RobertME, Liu J, etal.Prevention of graft-versus-host disease by inactivation of host antigen-presenting cells. Science (1999) 285:412-5. doi:10.1126/science.285.5426.412

37. Hashimoto D, Chow A, Greter M, Saenger Y, Kwan WH, Leboeuf M, et al. Pretransplant CSF-1 therapy expands recipient macrophages and ameliorates GvHD after allogeneic hematopoietic cell transplantation. J Exp Med (2011) 208:1069-82. doi:10.1084/jem.20101709

38. D’Aveni M, Rossignol J, Coman T, Sivakumaran S, Henderson S, Manzo T, et al. G-CSF mobilizes CD34+ regulatory monocytes that inhibit graft-versus-host disease. Sci Transl Med (2015) 281:281 ra42. doi:10.1126/scitranslmed.3010435

39. Reinhardt K, Foell D, Vogl T, Mezger M, Wittkowski H, Fend F, et al. Monocyte-induced development of Th17 cells and the release of S100 proteins are involved in the pathogenesis of graft-versus-host disease. J Immunol (2014) 193:3355-65. doi:10.4049/jimmunol.1400983 
40. Koehn BH, Apostolova P, Haverkamp JM, Miller JS, McCullar V, Tolar J, et al. GvHD-associated, inflammasome-mediated loss of function in adoptively transferred myeloid-derived suppressor cells. Blood (2015) 126:1621-8. doi:10.1182/blood-2015-03-634691

41. Schnurr M, Then F, Galambos P, Scholz C, Siegmund B, Endres S, et al. Extracellular ATP and TNF-alpha synergize in the activation and maturation of human dendritic cells. J Immunol (2000) 165:4704-9. doi:10.4049/ jimmunol.165.8.4704

42. Wilkin F, Duhant X, Bruyns C, Suarez-Huerta N, Boeynaems JM, Robaye B. The P2Y11 receptor mediates the ATP-induced maturation of human monocyte-derived dendritic cells. J Immunol (2001) 166(12):7172-7. doi:10.4049/ jimmunol.166.12.7172

43. Koyama M, Cheong M, Markey KA, Gartlan KH, Kuns RD, Locke KR, et al. Donor colonic CD103+ dendritic cells determine the severity of acute graftversus-host disease. J Exp Med (2015) 212:1303-21. doi:10.1084/jem.20150329

44. Kouzaki H, Iijima K, Kobayashi T, O'Grady SM, Kita H. The danger signal, extracellular ATP, is a sensor for an airborne allergen and triggers IL-33 release and innate Th2-type responses. J Immunol (2011) 186:4375-87. doi:10.4049/ jimmunol.1003020

45. Muller T, Robaye B, Vieira RP, Ferrari D, Grimm M, Jakob T, et al. The purinergic receptor $\mathrm{P} 2 \mathrm{Y} 2$ receptor mediates chemotaxis of dendritic cells and eosinophils in allergic lung inflammation. Allergy (2010) 65(12):1545-53. doi:10.1111/j.1398-9995.2010.02426.x

46. Ayata CK, Ganal SC, Hockenjos B, Willim K, Vieira RP, Grimm M, et al. Purinergic P2Y2 receptors promote neutrophil infiltration and hepatocyte death in mice with acute liver injury. Gastroenterology (2012) 143:1620-9. doi:10.1053/j.gastro.2012.08.049

47. Vanderstocken G, Van de Paar E, Robaye B, di Pietrantonio L, Bondue B, Boeynaems JM, et al. Protective role of P2Y2 receptor against lung infection induced by pneumonia virus of mice. PLoS One (2012) 7:e50385. doi:10.1371/ journal.pone.0050385

48. Schenk U, Westendorf AM, Radaelli E, Casati A, Ferro M, Fumagalli M, et al. Purinergic control of T cell activation by ATP released through pannexin-1 hemichannels. Sci Signal (2008) 1(39):ra6. doi:10.1126/scisignal.1160583

49. Faas MM, van der Schaaf G, Borghuis T, Jongman RM, van Pampus MG, de Vos P, et al. Extracellular ATP induces albuminuria in pregnant rats. Nephrol Dial Transplant (2010) 25(8):2468-78. doi:10.1093/ndt/gfq095

50. Klämbt V, Wohlfeil SA, Schwab L, Hülsdünker J, Ayata K, Apostolova P, et al. A novel function for P2Y2 in myeloid recipient-derived cells during GvHD. J Immunol (2015) 195:5795-804. doi:10.4049/jimmunol.1501357

51. Chernogorova P, Zeiser R. Ectonucleotidases in solid organ and allogeneic hematopoietic cell transplantation. J Biomed Biotechnol (2012) 12:208204-9. doi:10.1155/2012/208204

52. Deaglio S, Dwyer KM, Gao W, Friedman D, Usheva A, Erat A, et al. Adenosine generation catalyzed by $\mathrm{CD} 39$ and $\mathrm{CD} 73$ expressed on regulatory $\mathrm{T}$ cells mediates immune suppression. J Exp Med (2007) 204:1257-65. doi:10.1084/ jem.20062512

53. Sattler C, Steinsdoerfer M, Offers M, Fischer E, Schierl R, Heseler K, et al. Inhibition of T-cell proliferation by murine multipotent mesenchymal stromal cells is mediated by CD39 expression and adenosine generation. Cell Transplant (2011) 20(8):1221-30. doi:10.3727/096368910X546553

54. Gayle RB III, Maliszewski CR, Gimpel SD, Schoenborn MA, Caspary RG, Richards $\mathrm{C}$, et al. Inhibition of platelet function by recombinant soluble ecto-ADPase/CD39. J Clin Invest (1998) 101(9):1851-9. doi:10.1172/JCI1753

55. Enjyoji K, Sévigny J, Lin Y, Frenette PS, Christie PD, Esch JS, et al. Targeted disruption of cd39/ATP diphosphohydrolase results in disordered hemostasis and thromboregulation. Nat Med (1999) 5:1010-7. doi:10.1038/12447

56. Guckelberger O, Sun XF, Sévigny J, Imai M, Kaczmarek E, Enjyoji K, et al. Beneficial effects of CD39/ecto-nucleoside triphosphate diphosphohydrolase-1 in murine intestinal ischemia-reperfusion injury. Thromb Haemost (2004) 91:576-86. doi:10.1160/TH03-06-0373

57. Friedman DJ, Künzli BM, A-Rahim YI, Sevigny J, Berberat PO, Enjyoji K, et al. From the Cover: $\mathrm{CD} 39$ deletion exacerbates experimental murine colitis and human polymorphisms increase susceptibility to inflammatory bowel disease. Proc Natl Acad Sci U S A (2009) 106:16788-93. doi:10.1073/pnas.0902869106

58. Del Papa B, Pierini A, Sportoletti P, Baldoni S, Cecchini D, Rosati E, et al. The NOTCH1/CD39 axis: a Treg trip-switch for GvHD. Leukemia (2016). doi:10.1038/leu.2016.87
59. Zhang Y, Sandy AR, Wang J, Radojcic V, Shan GT, Tran IT, et al. Notch signaling is a critical regulator of allogeneic CD4+ T-cell responses mediating graft-versus-host disease. Blood (2011) 117:299-308. doi:10.1182/ blood-2010-03-271940

60. Gibson DJ, Elliott L, McDermott E, Tosetto M, Keegan D, Byrne K, et al. Heightened expression of CD39 by regulatory $\mathrm{T}$ lymphocytes is associated with therapeutic remission in inflammatory bowel disease. Inflamm Bowel Dis (2015) 21(12):2806-14. doi:10.1097/MIB.0000000000000566

61. Chrobak P, Charlebois R, Rejtar P, El Bikai R, Allard B, Stagg J. CD73 plays a protective role in collagen-induced arthritis. J Immunol (2015) 194(6):248792. doi:10.4049/jimmunol.1401416

62. Botta Gordon-Smith S, Ursu S, Eaton S, Moncrieffe H, Wedderburn LR. Correlation of low CD73 expression on synovial lymphocytes with reduced adenosine generation and higher disease severity in juvenile idiopathic arthritis. Arthritis Rheumatol (2015) 67(2):545-54. doi:10.1002/ art.38959

63. Blume C, Felix A, Shushakova N, Gueler F, Falk CS, Haller H, et al. Autoimmunity in CD73/Ecto-5'-nucleotidase deficient mice induces renal injury. PLoS One (2012) 7(5):e37100. doi:10.1371/journal.pone. 0037100

64. Bynoe MS, Waickman AT, Mahamed DA, Mueller C, Mills JH, Czopik A. CD73 is critical for the resolution of murine colonic inflammation. J Biomed Biotechnol (2012) 2012:260983. doi:10.1155/2012/260983

65. Tsukamoto H, Chernogorova P, Ayata K, Gerlach UV, Rughani A, Ritchey JW, et al. Deficiency of CD73/ecto-5'-nucleotidase in mice enhances acute graft-versus-host disease. Blood (2012) 119:4554-64. doi:10.1182/ blood-2011-09-375899

66. Wang L, Fan J, Chen S, Zhang Y, Curiel TJ, Zhang B. Graft-versus-host disease is enhanced by selective CD73 blockade in mice. PLoS One (2013) 8:e58397. doi:10.1371/journal.pone.0058397

67. Thompson LF, Tsukamoto H, Chernogorova P, Zeiser R. A delicate balance: CD73-generated adenosine limits the severity of graft vs. host disease but also constrains the allogeneic graft vs. tumor effect. Oncoimmunology (2013) 2:e22107. doi:10.4161/onci.22107

68. Yang J, Jian R, Yu J, Zhi X, Liao X, Yu J, et al. CD73 regulates vascular smooth muscle cell functions and facilitates atherosclerotic plaque formation. IUBMB Life (2015) 67(11):853-60. doi:10.1002/iub.1448

69. Wirsdorfer F, de Leve S, Cappuccini F, Eldh T, Meyer AV, Gau E, et al. Extracellular adenosine production by ecto-5'-nucleotidase (CD73) enhances radiation-induced lung fibrosis. Cancer Res (2016) 76(10):3045-56. doi:10.1158/0008-5472.CAN-15-2310

70. Wu C, Zhao Y, Xiao X, Fan Y, Kloc M, Liu W, et al. Graft-infiltrating macrophages adopt an $\mathrm{m} 2$ phenotype and are inhibited by purinergic receptor P2X7 antagonist in chronic rejection. Am J Transplant (2016) 16(9):2563-73. doi:10.1111/ajt.13808

71. Menzies RI, Howarth AR, Unwin RJ, Tam FW, Mullins JJ, Bailey MA. Inhibition of the purinergic P2X7 receptor improves renal perfusion in angiotensin-II-infused rats. Kidney Int (2015) 88(5):1079-87. doi:10.1038/ ki.2015.182

72. Wang S, Zhao J, Wang H, Liang Y, Yang N, Huang Y. Blockage of P2X7 attenuates acute lung injury in mice by inhibiting NLRP3 inflammasome. Int Immunopharmacol (2015) 27(1):38-45. doi:10.1016/j.intimp.2015.04.035

73. Zhong X, Zhu F, Qiao J, Zhao K, Zhu S, Zeng L, et al. The impact of P2X7 receptor antagonist, brilliant blue $\mathrm{G}$ on graft-versus-host disease in mice after allogeneic hematopoietic stem cell transplantation. Cell Immunol (2016). doi:10.1016/j.cellimm.2016.07.014

74. Qiao J, Huang Y, Xia Y, Chu P, Yao H, Xu L, et al. Busulfan and cyclosphamide induce liver inflammation through NLRP3 activation in mice after hematopoietic stem cell transplantation. Sci Rep (2015) 5:17828. doi:10.1038/srep17828

75. Qiao J, Wu J, Li Y, Xia Y, Chu P, Qi K, et al. Blockage of caspase-1 activation ameliorates bone marrow inflammation in mice after hematopoietic stem cell transplantation. Clin Immunol (2016) 162:84-90. doi:10.1016/ j.clim.2015.11.012

76. Keystone EC, Wang MM, Layton M, Hollis S, McInnes IB. Clinical evaluation of the efficacy of the P2X7 purinergic receptor antagonist AZD9056 on the signs and symptoms of rheumatoid arthritis in patients with active disease despite treatment with methotrexate or sulphasalazine. Ann Rheum Dis (2012) 71:1630-5. doi:10.1136/annrheumdis-2011-143578 
77. Stock TC, Bloom BJ, Wei N, Ishaq S, Park W, Wang X, et al. Efficacy and safety of CE-224,535, an antagonist of P2X7 receptor, in treatment of patients with rheumatoid arthritis inadequately controlled by methotrexate. J Rheumatol (2012) 39(4):720-7. doi:10.3899/jrheum.110874

78. Eser A, Colombel JF, Rutgeerts P, Vermeire S, Vogelsang H, Braddock M, et al. Safety and efficacy of an oral inhibitor of the purinergic receptor P2X7 in adult patients with moderately to severely active Crohn's disease: a randomized placebo-controlled, double-blind, phase IIa study. Inflamm Bowel Dis (2015) 21(10):2247-53. doi:10.1097/MIB.0000000000000514

79. Flogel U, Burghoff S, van Lent PL, Temme S, Galbarz L, Ding Z, et al. Selective activation of adenosine A2A receptors on immune cells by a CD73-dependent prodrug suppresses joint inflammation in experimental rheumatoid arthritis. Sci Transl Med (2012) 4(146):146ra108. doi:10.1126/scitranslmed. 3003717

80. Liu Y, Zou H, Zhao P, Sun B, Wang J, Kong Q, et al. Activation of the adenosine A2A receptor attenuates experimental autoimmune encephalomyelitis and is associated with increased intracellular calcium levels. Neuroscience (2016) 330:150-61. doi:10.1016/j.neuroscience.2016.05.028

81. Wang L, Wan H, Tang W, Ni Y, Hou X, Pan L, et al. Critical roles of adenosine A2A receptor in regulating the balance of Treg/Th17cells in allergic asthma. Clin Respir J (2016). doi:10.1111/crj.12503

82. Lappas CM, Liu PC, Linden J, Kang EM, Malech HL. Adenosine A2A receptor activation limits graft-versus-host disease after allogenic hematopoietic stem cell transplantation. J Leukoc Biol (2010) 87:345-54. doi:10.1189/jlb. 0609388

83. Han KL, Thomas SV, Koontz SM, Changpriroa CM, Ha SK, Malech HL, et al. Adenosine $\mathrm{A}_{2} \mathrm{~A}$ receptor agonist-mediated increase in donor-derived regulatory $\mathrm{T}$ cells suppresses development of graft-versus-host disease. J Immunol (2013) 190:458-68. doi:10.4049/jimmunol.1201325
84. Chen JF, Eltzschig HK, Fredholm BB. Adenosine receptors as drug targets what are the challenges? Nat Rev Drug Discov (2013) 12:265-86. doi:10.1038/ $\operatorname{nrd} 3955$

85. Schönle A, Hartl FA, Mentzel J, Nöltner T, Rauch KS, Prestipino A, et al. Caveolin-1 regulates TCR signal strength and regulatory $\mathrm{T}$ cell differentiation into alloreactive T cells. Blood (2016) 127:1930-9. doi:10.1182/ blood-2015-09-672428

86. Hechinger AK, Smith BA, Flynn R, Hanke K, McDonald-Hyman C, Taylor PA, et al. Therapeutic activity of multiple common gamma chain cytokine inhibition in acute and chronic GvHD. Blood (2015) 125:570-80. doi:10.1182/ blood-2014-06-581793

87. Spoerl S, Mathew NR, Bscheider M, Schmitt-Graeff A, Chen S, Mueller T, et al. Activity of therapeutic JAK $1 / 2$ blockade in graft-versus-host disease. Blood (2014) 123:3832-42. doi:10.1182/blood-2013-12-543736

88. Zeiser R, Burchert A, Lengerke C, Verbeek M, Maas-Bauer K, Metzelder SK, et al. Ruxolitinib in corticosteroid-refractory graft-versus-host disease after allogeneic stem cell transplantation: a multi-center survey. Leukemia (2015) 29:2062-8. doi:10.1038/leu.2015.212

Conflict of Interest Statement: The authors declare that the research was conducted in the absence of any commercial or financial relationships that could be construed as a potential conflict of interest.

Copyright (c) 2016 Apostolova and Zeiser. This is an open-access article distributed under the terms of the Creative Commons Attribution License (CC BY). The use, distribution or reproduction in other forums is permitted, provided the original author(s) or licensor are credited and that the original publication in this journal is cited, in accordance with accepted academic practice. No use, distribution or reproduction is permitted which does not comply with these terms. 